\title{
Serum plasminogen activator inhibitor 1 (PAl-1) and intra-ocular pressure (IOP): the Guangzhou biobank cohort study
}

\author{
J Heggie*, K Tanner, M Protty, GN Thomas \\ From International Conference for Healthcare and Medical Students 2011 \\ Dublin, Ireland. 4-5 November 2011
}

\section{Introduction}

Increased intraocular pressure (IOP) is a major risk factor for developing ocular disease such as primary open-angle glaucoma. Plasminogen activator inhibitor 1 (PAI-1) plays a role in the turnover and degradation of extracellular matrix proteins (ECM) which are thought to play a role in the pathogenesis of increased IOP. To determine if an independent association exists between serum PAI-1 and IOP in humans.

\section{Methods}

A cross-sectional study with participants from the Guangzhou biobank cohort study (GBCS-CVS) aged 50-85 years were recruited and received a medical checkup including measurement of serum PAI-1, IOP, blood pressure, fasting LDL- and HDL-cholesterol, glucose and obesity measures. Information on socioeconomic and lifestyle factors was also collected. Subjects were divided into tertiles based on serum PAI-1 and a logistic regression analysis was performed to derive an odds ratio for having high IOP for each tertile. Personal, social and vascular confounders were adjusted for.

\section{Results}

The risk of increased IOP was significantly raised with higher serum PAI-1, with adjusted odds ratios (95\% confidence intervals) for second and third tertiles of 1.31 (0.81-2.12) and 1.81 (1.15-2.83), respectively. Haematocrit, glycosylated haemoglobin (HbA1c), heart rate, and high-density lipoprotein (HDL-C) were the only vascular risk factors positively associated with serum PAI-1 levels (p from 0.03 to $<0.01$ ).

College of Medical and Dental Sciences, University of Birmingham, UK

\section{Conclusions}

There is a strong relationship between serum PAI-1 and IOP in this older Chinese population. Further studies are needed to confirm these findings in this and other populations.

Published: 9 July 2012

doi:10.1186/1753-6561-6-S4-026

Cite this article as: Heggie et al.: Serum plasminogen activator inhibitor 1 (PAl-1) and intra-ocular pressure (IOP): the Guangzhou biobank cohort study. BMC Proceedings 2012 6(Suppl 4):O26.
Submit your next manuscript to BioMed Central and take full advantage of:

- Convenient online submission

- Thorough peer review

- No space constraints or color figure charges

- Immediate publication on acceptance

- Inclusion in PubMed, CAS, Scopus and Google Scholar

- Research which is freely available for redistribution
() Biomed Central 